\title{
Young adults' relationship intentions towards their cell phone network operators
}

\author{
L. Kruger and P.G. Mostert* \\ WorkWell: Research Unit for Economic and Management Sciences, \\ North-West University (Potchefstroom Campus) \\ School of Business Management, Private Bag X6001, \\ Potchefstroom 2520. Republic of South Africa 2520 \\ pierre mostert@nwu.ac.za \\ Received April 2011
}

\begin{abstract}
Marketers use relationship marketing to establish mutually beneficial long-term relationships with their customers as a means to retain them in the competitive market environment. Relationship marketing should not be used to target every customer as not all customers want to build long-term relationships with organisations. In order to identify the most profitable customers for relationship marketing, organisations should consider their customers' relationship intentions to form long-term relationships with them. The primary objective of this study was to determine young adults' (aged 18 to 25) relationship intentions towards the South African cell phone network operators they use, namely Vodacom, MTN or Cell C. Five constructs (involvement, expectations, forgiveness, feedback and fear of relationship loss) were used to measure relationship intention. Data was collected from 315 respondents at a tertiary education institution in South Africa by means of a non-probability convenience sample. Findings indicate that a relatively high percentage of respondents have a high relationship intention towards their cell phone network operator and that respondents with high relationship intentions are more Involved with and Fear losing their relationship with their cell phone network operator than respondents with low relationship intentions
\end{abstract}

*To whom all correspondence should be addressed.

\section{Introduction}

Prior to the paradigm shift towards the notion of relationship marketing, marketers' efforts were primarily described as transactional marketing (Payne, 2006:11). In contrast to transactional marketing, relationship marketing entails that organisations foster long-term mutually beneficial relationships with customers and other stakeholders (Baran, Galka \& Strunk, 2008:48; Payne, 2006:11; Evans, O’Malley \& Patterson, 2004:210).

Relationship marketing is used to increase value for customers by responding to identified customer needs (Pride $\&$ Ferrell, 2010:14) and organisations focus on relationship marketing because long-term customer relationships are favourable for the organisation's profitability, as a satisfied customer is more likely to spend on additional products and services and spread favourable word-of-mouth communication than short-term customers are likely to do (Liang \& Wang, 2006:124).

Most organisations, however, have both transactional and relational customers (Baran et al., 2008:107) and it is contended that not all customers necessarily need or want a relationship with an organisation (Steyn, Mostert \& De Jager, 2008:139, 146). Although customers with a transactional intention can constitute a great volume of the business of an organisation, any organisational resources spent on building a relationship with these customers will be wasted (Liang \& Wang, 2006:139-140; Kumar, Bohling \& Ladda, 2003:668). Organisations should therefore focus their relationship marketing efforts on customers with a relationship intention (Kumar et al., 2003:669), instead of surmising that relationships can be formed with all customers (Odekerken-Schröder, De Wulf \& Schumacher, 2003:178).

Since young adults are becoming increasingly important in today's market arena due to their numbers and buying power (Ling, 2008:890), cell phone network operators should endeavour to identify those young adults who want to form long-term relationships with the organisation. The importance of cell phone network operators in South Africa becomes apparent when considering that in a 2009 survey by Doke (2009:3), Vodacom was voted the second overall favourite brand of South Africa. A maintained relationship between the young adult and a cell phone network operator could ultimately result in higher profitability for the organisation, especially if young adults are loyal to their cell phone network operators over a long period of time. Also, by identifying and building relationships through relationship marketing with young adults with a high relationship intention, cell phone network operators will in all probability retain these customers once they gain more disposable income when they start to work or through career advancements. For this reason, those young adults with a relationship intention should be identified by the marketer. 
The aim of this study is therefore to examine young adults' relationship intentions towards their cell phone network operators using the five relationship intention constructs as proposed by Kumar et al. (2003:670), namely involvement, expectations, forgiveness, feedback and fear of relationship loss.

\section{Theoretical background}

\section{Relationship marketing}

Blythe (2006:372) suggests that the origin of relationship marketing can be found in the Japanese keiretsu system, which entails that all organisations in the value chain become extremely involved and linked through arrangements and high degrees of trust and loyalty. Relationship marketing therefore requires cooperation and collaboration through which mutual economic value at reduced cost is experienced by both parties in a business relationship (Parvatiyar \& Sheth, 2000:9). The focus on value enhancement ensures that both parties benefit from more satisfying exchanges. In this study, relationship marketing in terms of customers will be emphasised.

Pride and Ferrell (2010:14) state that successful marketers respond to customer needs by increasing value to customers over time, while Baran et al. (2008:98) are of the opinion that relationship marketing forms part of the essence of marketing in providing value. Wong and Hsu (2008:79) explain that relationship marketing continually deepens the customer's trust in the organisation, which in turn results in a better understanding of customer needs as the organisation can collect customer information from the trusting customer. Over time, the interaction between the organisation and customers turns into a relationship that enables cooperation and mutual dependency (Pride \& Ferrell, 2010:14).

Payne (2006:9) maintains that one of the key principles of relationship marketing is an emphasis on the retention of profitable customers through maximising the lifetime-value of the customer's relationship. According to Wilson, Zeithaml, Bitner and Gremler (2008:158-160), the successful use of relationship marketing results in lower costs for the organisation as it is less expensive to retain customers than to attract new customers. Furthermore, organisations will benefit from loyalty of customers through repeat sales and referrals resulting in increased sales, market share and profits. This argument is supported by Steyn et al. (2008:140) and Payne (2006:9) who suggest that the benefits of relationship marketing for the organisation are lodged in customer retention, which results in lower business costs, an increase in customer spending, referrals and price-premiums.

However, despite organisations' best intentions to build relationships with customers, not all customers want to form long-term relationships with organisations. Tuominen (2007:182) and Odekerken-Schröder et al. (2003:178) support this view by stating that valuable resources are wasted if the organisation applies relationship marketing strategies to customers not desiring a relationship with the organisation. It is therefore in the best interest of the organisation to identify those customers who want to form a relationship with them.

\section{Relationship intention}

Kumar et al. (2003:667, 669) define relationship intention as the customer's intention to build a relationship with an organisation when buying a product or making use of a service provided by the organisation. According to Steyn et al. (2008:144), customers have a relationship intention when they are emotionally attached to the organisation, value a relationship approach and view loyalty, trust and commitment as important factors in the relationship between the organisation and the customer.

Berry (2000:156-157) propounds that some customers are more profitable than others, and some customers may therefore be unprofitable to serve. Also, some customers may be profitable as transactional customers even if they are not relationship customers (Lovelock \& Wirtz, 2007:364). For this reason, organisations may choose to apply dual strategies for both transactional and relationship marketing where specific market segments are targeted by means of these respective strategies. Egan (2004:92) agrees that organisations should choose a strategy (transactional or relational or a combination of both) appropriate to the particular situation because, as Evans et al. (2004:286) explain, customers are not equally profitable; neither are all customers profitable with regard to relationship marketing.

Kumar et al. (2003:670) propose five constructs that can be used to measure the relationship intention of customers, namely involvement, expectations, forgiveness, feedback and fear of relationship loss.

\section{Involvement}

Kumar et al. (2003:670) state that involvement in terms of relationship intention should be defined as the degree to which customers would willingly engage in relationship activities in the absence of obligation or coercion. Engeseth (2006:36-37) emphasises the importance of customer involvement to the organisation by regarding customer involvement as the most effective way in which an organisation can remain relevant to customers. It is easier for organisations to move closer to those customers willing to get involved with the organisation and to exceed their expectations through this close relationship than to simply wage war against competitors in the hope to gain more market share than competitors.

When customers are more involved with the product or service, have accumulated more experience with their service providers and enjoy the relational benefits from their service relationships, their value perceptions will be medium to high (Ruiz, Castro \& Armario, 2007:1103). The opposite is also true. Ha (2004:193, 200-201) remarks that when a customer builds a solid foundation with the organisation, the customer becomes involved with the organisation. This means that there is a correlation between involvement and relationship marketing effectiveness. Organisations should thus identify involved customers for relationship building 
because these customers are most likely to engage in a relationship with the organisation (Varki \& Wong, 2003:89).

Involvement should therefore be viewed as instrumental in developing a relationship with customers, thereby emphasising the necessity for organisations to identify highly involved customers in order to build long-term relationships with them (Seiders, Voss, Grewal \& Godfrey, 2005:39).

\section{Expectations}

Liang and Wang (2006:120-121) are of the opinion that the investment of time, effort and other irrecoverable resources in a relationship is the motivation for different parties to sustain the relationship and develop expectations for the relationship. For this reason, Kumar et al. (2003:670) state that customer expectations are automatically developed when purchasing a product or service. When a customer has high expectations of an organisation, it is proof that the customer is concerned about the quality of the product or service and is also indicative that the customer has an intention to build a relationship with the organisation. Therefore, customers with high expectations will be involved in service delivery to enhance the quality of products and services.

Buttle (2009:263-267), Wilson et al. (2008:56-59) and Lovelock and Wirtz (2007:47-49) identified four components of customer expectations relating to service quality and satisfaction, implying that the customer is concerned with the organisation and has a relationship intention. Desired service levels are viewed as a combination between what customers believe the organisation can and should deliver to satisfy their personal needs; adequate service levels are the minimum service levels that customers will accept without being dissatisfied; predicted service levels influence these adequate service levels; and the zone of tolerance is the extent of service variation that customers are willing to accept.

Higher expectations lead to greater customer relationship intention (Kumar et al., 2003:670). Loyal customers expect to have better relationships with the organisation than nonloyal customers. Such high expectations and the fact that customers are concerned with the organisation show a high relationship intention (Kumar et al., 2003:670).

\section{Forgiveness}

Kumar et al. (2003:670) posit that customers with the intention of building a relationship with an organisation are more willing to continue support of the organisation, even when expectations are not always met. Steyn et al. (2008:145) maintain that loyal customers will be more willing to forgive service failures by overlooking a negative outcome. It was found that customers with higher expectations, who are willing to forgive a service failure and accept the service recovery of organisations, will have higher relationship intentions (Kumar et al., 2003:670).

Research indicates that a high relationship intention will make the customer more tolerant of service failures and reduce the likelihood of the customer defecting after experiencing a service failure (Kumar et al., 2003:670). However, despite this view, Lovelock and Wirtz (2007:395396) caution that customers (with a high relationship intention) may forgive a first service failure, but could become disillusioned when failures re-occur.

\section{Feedback}

Kumar et al. (2003:670) state that customers, who believe in giving both positive and negative feedback to the organisation, have a higher relationship intention and that customers, who do not expect a reward when providing feedback, have a higher level of relationship intention. Feedback includes customer complaints, suggestions, compliments and inquiries (Lovelock \& Wirtz, 2007:410, 412).

Loyal customers are most likely to provide data to the organisation as they trust the organisation, and expect the organisation to use the data with discretion and to their benefit (Gamble, Stone, Woodcock \& Foss, 2006:210). It is also argued by Lovelock and Wirtz (2007:392-395) that when customers give feedback, the organisation can use this information to provide service recovery if necessary.

Kumar et al. (2003:670) regard customers' concerns and involvement with the organisation to be portrayed through their belief that they can, through their feedback in the form of complaining, be involved in bettering organisational performance. Customers portraying this behaviour indicate high relationship intention.

\section{Fear of relationship loss}

Kumar et al. (2003:670) state that customers with an intention to build a relationship with an organisation fear losing their relationship with the organisation. Emotionally attached customers have a high involvement with the organisation and feel guilty when considering other options; they fear losing their emotional attachment to the organisation.

Buttle (2009:263) maintains that a sense of well-being occurs when a customer establishes an ongoing relationship with an organisation. The social bonding that takes place between the organisation and customers ensures the personalisation and customisation of the relationship. Organisations can enhance these bonds by, for instance, being reliable, addressing customers by name, and providing continuity of service through the same customer contact staff (Lamb, Hair, McDaniel, Boshoff \& Terblanche, 2008:12).

Steyn et al. (2008:140) further propound that because of the nature of services, the transactions between the organisation and the customer can be viewed as social encounters. For this reason, customers will take switching barriers, nonmonetary costs and risks associated with ending the relationship with the organisation into consideration. It can be stated that when bonds are strong and non-monetary costs as well as risks are high, customers with a relationship 
intention will fear losing the relationship with the organisation (Kumar et al., 2003:670).

\section{Relationship length}

Organisations generally follow a relationship marketing approach with their customers in an effort to build and maintain a bond with them over time. By doing so, organisations hope that the relationship would become more profitable as it lengthens (Little \& Marandi, 2003:46). However, customers do not offer the same profitability at every moment during their relationships with organisations, which should be taken into consideration when referring to the possible link between relationship length and profitability (Kasper, Van Helsdingen \& Gabbott, 2006:78).

Concerning the motive to form long-term relationships with customers with the view of increased profitability, Kumar et al. (2003:670) warn that customers' intentions to develop a relationship do not necessarily depend on the length of the relationship with them.

\section{Problem statement and research objectives}

Previous studies on relationship intention in South Africa focussed on the validity of the five constructs of relationship intention posited by Kumar et al. (2003:670), with a view to measure the relationship intention of customers in the shortterm insurance industry (De Jager, 2006:5), the motor vehicle industry (Mentz, 2007:2) and the banking and lifeinsurance industries (Delport, 2009:5). As no studies have been done in South Africa on the relationship intention of customers in the cellular industry, the decision was made to determine young adults' relationship intentions towards their cell phone network operators.

The cellular industry was chosen as cell phone network operators in South Africa have a strong brand presence (Doke, 2009:3) and young adults were selected as study population since young adults attach great value to technology (Moroz, 2008:26), they view cell phone network operators as important brands (Doke, 2008:3), and the choice of a cell phone network operator is important to them. When selecting a product or service, young adults have proven to display much interest on product categories that they view as important, use heavily and are well acquainted with (Belch, Krentler \& Willis-Flurry, 2005:570). Since young adults are becoming increasingly important in today's market arena due to their numbers and buying power (Ling, 2008:890), cell phone network operators should endeavour to identify those young adults who want to form long-term relationships with the organisation.

The purpose of this study is therefore to examine young adults' relationship intentions towards their cell phone network operators. The following objectives were accordingly set for the study:

- $\quad$ to determine whether the five relationship intention constructs proposed by Kumar et al. (2003:670) are valid to measure young adults' relationship intentions towards their cell phone network operators;
- $\quad$ to determine whether differences exist between young adults showing high relationship intention and those showing low relationship intention for the constructs used to measure relationship intention;

- $\quad$ to determine whether there are differences between respondents in terms of the length of their relationship with the cell phone network operators; and

- to determine whether there are differences between young adults who subscribe to the different cell phone network operators with regard to their relationship intentions.

\section{Method}

\section{Sampling}

The population of this study comprised young adults between the ages of 18 and 25 years old, studying at a wellknown South African university. A convenience sample of 315 respondents was drawn from this population. Not only are students an important market segment, but Corder, Phillips and Tybout (in Laroche, Ueltschy, Abe, Cleveland \& Yannopoulos, 2004:63) stated that university students can be appropriate as they are more likely to be homogenous on certain demographic features and they are familiar with the product.

\section{Design and measurement instrument}

The current study followed a two-stage design. First, qualitative research in the form of two focus groups conducted among the target population was used to collect background knowledge on the cell phone network operators' features that young adults view as important and why different network operators are used. The information gathered from the focus group was used to construct a part of the final questionnaire that was used as measurement instrument in the second stage of this study.

To measure respondents' relationship intentions, a questionnaire was designed based on the questionnaire proposed by Kumar et al. (2003:675-676) and adapted by De Jager (2006:166), Mentz (2007:217) and Delport (2009:91-101). Questions were changed with a view to improve the reliability and validity of the research as previous South African studies measuring relationship intention all suffered from low Cronbach alpha values (Delport, 2009:31; Mentz, 2007:120; De Jager, 2006:18). A pilot study of the revised measure of relationship intention was then conducted with 202 young adults from the target population and this improved measure was used in the final questionnaire.

\section{Data analysis}

Exploratory factor analysis (EFA) and confirmatory factor analysis (CFA) were used to identify (during the pilot study) and then to validate (during the main study) the five constructs proposed by Kumar et al. (2003:675-676) to measure relationship intention. T-tests and ANOVAs were used to determine statistical significance. For the purposes 
of this study, a p-value of $\leq 0.05$ will be regarded as indicative of statistical significance (Zikmund \& Babin, 2010:542). Although statistical significance shows whether statistical differences exist between variables, it does not indicate the strength of the significance. It was therefore decided to, in addition to determining statistical significance, also determine the practical significance by employing Cohen's d-values. Sprinthall (2003:178) and Steyn (1999:3) explain that the practical significance of the difference between two means is determined by Cohen's effect size symbolised as d. Interpretation of results would therefore be based on Cohen's d-values. The effect size reported as $\mathrm{d}$ is considered to be small at 0.20 , medium at 0.50 and strong and practically significant at 0.80 or larger (Cohen, 1988:25-26). The formula for the effect size is (Steyn, 1999:12):

$$
\mathrm{d}=\frac{\left|\overline{\mathrm{x}}_{1}-\overline{\mathrm{x}}_{2}\right|}{\mathrm{s}_{\max }}
$$

where:

- $\quad \mathrm{d}=$ effect size;

- $\overline{\mathrm{x}}_{1}-\overline{\mathrm{x}}_{2}$ is the difference between means of two compared groups; and

- $\mathrm{S}_{\max }$ is the maximum standard deviation of the two compared groups.

\section{Results}

\section{Sample profile}

A total of 315 respondents completed the questionnaire and the sample mainly consisted of young adults aged 18 to 24 years old $(97 \%)$, with only $3 \%$ of respondents being older than 24 years. More females $(61 \%)$ participated in this study than males $(39 \%)$. More than $50 \%$ of respondents' monthly cell phone expenses amounted to between R101 and R250. The distribution between the different cell phone network operators were: Vodacom (37\%), MTN (32\%) and Cell C (31\%). The majority of all respondents (77.8\%) have contracts with their cell phone network operators [Vodacom (78\%), MTN (74\%) and Cell C (81\%)].

\section{Reliability and validity}

A pilot study was conducted among 202 respondents from the target population using the revised questionnaire. Five factors relating to the five constructs as proposed by Kumar et al. (2003:675-676) to measure relationship intention were identified from the exploratory factor analysis, namely expectations, feedback, involvement, forgiveness and fear of relationship loss. Cronbach alpha values for each factor were $>0,7$ (ranging from 0,81 to 0,87 ), indicating a high level of reliability between items in the measuring instrument for relationship intention. The improved measure of relationship intention was therefore used in the final questionnaire used in the study to determine respondents' relationship intentions.
A confirmatory factor analysis was performed to determine whether the interval scale items used in the final questionnaire to measure relationship intention can be grouped according to the factors identified by the exploratory factor analysis performed during the pilot study. Table 1 indicates the Cronbach alpha values for the factors obtained during the confirmatory factor analysis.

Table 1: Cronbach alpha values

\begin{tabular}{c|l|c}
\hline Factor & \multicolumn{1}{|c|}{ Factor label } & Cronbach alpha \\
\hline $\mathbf{1}$ & Expectations & 0,85 \\
\hline $\mathbf{2}$ & Feedback & 0,84 \\
\hline $\mathbf{3}$ & Involvement & 0,85 \\
\hline $\mathbf{4}$ & Forgiveness & 0,82 \\
\hline $\mathbf{5}$ & Fear of relationship loss & 0,87 \\
\hline
\end{tabular}

The results in Table 1 indicate that the five factors identified through the exploratory factor analysis in the pilot study of the relationship intention measure, are valid to measure respondents' relationship intentions. It can therefore be concluded that the five relationship constructs proposed by Kumar et al. (2003:670) are valid to measure young adults' relationship intentions towards their cell phone network operators.

\section{Categorising respondents according to their relationship intentions}

Validation questions were used as suggested by Kumar et al. (2003:675) to categorise respondents as having either a high or low relationship intention by determining both their intention to maintain their relationship with their cell phone network operators as well as establishing their intentions to build a long-term relationship with their cell phone network operators. Respondents answering in the affirmative to both validation questions were, therefore, considered to have a high relationship intention, whereas respondents who answered 'no' to any of the two questions were, on the other hand, considered as having a low relationship intention. Table 2 categorises respondents according to their relationship intentions by also considering the demarcation according to cell phone network operator.

Table 2: Respondents' relationship with their cell phone network operator

\begin{tabular}{l|c|c|c|c|c|c|c|c}
\hline \multirow{2}{*}{$\begin{array}{c}\text { Relationship } \\
\text { intention }\end{array}$} & \multicolumn{2}{|c|}{$\begin{array}{c}\text { Sample } \\
\mathbf{n = 3 1 5}\end{array}$} & \multicolumn{2}{c|}{$\begin{array}{c}\text { Vodacom } \\
\mathbf{n = 1 1 5}\end{array}$} & \multicolumn{2}{c|}{$\begin{array}{c}\text { MTN } \\
\mathbf{n = 1 0 1}\end{array}$} & \multicolumn{2}{c}{$\begin{array}{c}\text { Cell C } \\
\mathbf{n = 9 9}\end{array}$} \\
\cline { 2 - 9 } & $\mathbf{F}$ & $\mathbf{\%}$ & $\mathbf{F}$ & $\mathbf{\%}$ & $\mathbf{F}$ & $\mathbf{\%}$ & $\mathbf{F}$ & $\mathbf{\%}$ \\
\hline Yes & 231 & 73,3 & 107 & 93,0 & 69 & 68,3 & 55 & 55,6 \\
\hline No & 84 & 26,7 & 8 & 7,0 & 32 & 31,7 & 44 & 44,4 \\
\hline Total & 315 & 100 & 115 & 100 & 101 & 100 & 99 & 100 \\
\hline
\end{tabular}

From Table 2 it can be deduced that the majority of all respondents $(73.3 \%)$ have a high relationship intention and 84 respondents $(26.7 \%)$ have a low relationship intention. Concerning the different cell phone network operators, the highest percentage of respondents using Vodacom (93.0\%) have high relationship intentions followed by respondents using MTN (68.3\%) and lastly, Cell C (55.6\%). 
Differences between respondents with high relationship intentions and respondents with low relationship intentions

In order to determine the statistically significant differences between respondents with high relationship intentions and those respondents with low relationship intentions in terms of the five relationship intention factors, independent t-tests were performed. Table 3 shows the results from the t-tests to determine the difference between the means for respondents with high relationship intentions and low relationship intentions for the five factors used to measure relationship intention.

Table 3: Relationship intention scored for high and low relationship intention respondents

\begin{tabular}{|c|c|c|c|c|c|c|}
\hline Factors & Group & $\mathbf{n}$ & Mean & SD & $\begin{array}{c}\text { p- } \\
\text { value* }\end{array}$ & $\begin{array}{c}\text { d- } \\
\text { value }\end{array}$ \\
\hline \multirow{2}{*}{$\begin{array}{l}\text { Factor 1: } \\
\text { Expectations }\end{array}$} & High & 231 & 4,27 & 0,64 & \multirow{2}{*}{0,0009} & \multirow{2}{*}{0,41} \\
\hline & Low & 84 & 3,93 & 0,82 & & \\
\hline \multirow{2}{*}{$\begin{array}{l}\text { Factor 2: } \\
\text { Feedback }\end{array}$} & High & 231 & 3,49 & 0,84 & \multirow{2}{*}{0,0120} & \multirow{2}{*}{0,31} \\
\hline & Low & 84 & 3,17 & 1,02 & & \\
\hline \multirow{2}{*}{$\begin{array}{l}\text { Factor 3: } \\
\text { Involvement }\end{array}$} & High & 231 & 3,80 & 0,71 & \multirow{2}{*}{$<0,0001$} & \multirow{2}{*}{1,24} \\
\hline & Low & 84 & 2,76 & 0,83 & & \\
\hline \multirow{2}{*}{$\begin{array}{l}\text { Factor 4: } \\
\text { Forgiveness }\end{array}$} & High & 231 & 2,76 & 0,83 & \multirow{2}{*}{$<0,0001$} & \multirow{2}{*}{0,58} \\
\hline & Low & 84 & 2,27 & 0,85 & & \\
\hline \multirow{2}{*}{$\begin{array}{l}\text { Factor 5: } \\
\text { Fear of } \\
\text { relationship } \\
\text { loss }\end{array}$} & High & 231 & 2,90 & 1,00 & \multirow[b]{2}{*}{$<0,0001$} & \multirow[b]{2}{*}{$\mathbf{0 , 8 9}$} \\
\hline & Low & 84 & 2,01 & 0,98 & & \\
\hline
\end{tabular}

From Table 3 it can be observed that a large effect size $(\mathrm{d}=1.24)$, which is practically significant, was found between respondents with high relationship intentions and those with low relationship intentions for factor 3 (Involvement). Furthermore, the mean scores show that respondents with high relationship intentions (mean=3.80) agreed more pertinently with the items concerning Involvement than respondents with low relationship intentions (mean=2.76). It can therefore be deduced that respondents with high relationship intentions are more Involved with their cell phone network operator than respondents with low relationship intentions. This finding concurs with results from Varki and Wong (2003:89).

A large effect size $(\mathrm{d}=0,89)$, which is practically significant, was also found for factor 5 (Fear of relationship loss) when comparing these two groups. By considering the mean scores, it can be seen that respondents with high relationship intentions (mean=2,90) agreed more with those items comprising factor 5 than respondents with low relationship intentions (mean=2.01). For this reason, respondents with high relationship intentions Fear losing their relationship with their cell phone network operator more than respondents with low relationship intentions.

The other three factors, factor 4 (Forgiveness), factor 1 (Expectations) and factor 2 (Feedback) had medium and small effect sizes, indicating that no practically significant differences exist between the relationship intention of respondents with high relationship intentions and respondents with low relationship intentions with regard to these factors.

\section{Length of relationship with cell phone network operator}

Results indicated that slightly more than half of all the respondents (nearly 54\%) have used their cell phone network operators for a period shorter than five years, while $43 \%$ have used their cell phone network operator for five years, but less than 10 years. The length of relationship with the cell phone network operator of the majority of respondents using Vodacom (64\%) and MTN (nearly 39\%) is five years or longer, but less than 10 years, while the length of relationship of the majority respondents using Cell $\mathrm{C}$ as their cell phone network operator is three years or longer, but less than five years $(30 \%)$.

In order to determine whether statistically significant differences exist between respondents with different lengths of relationships with their cell phone network operators in terms of the relationship intention factors, one-way ANOVAs were performed. However, no statistically significant differences were found for any of the five factors in terms of respondents' relationship lengths.

\section{Differences between respondents using Vodacom, MTN and Cell C}

In order to determine whether statistically significant differences exist between respondents from the different cell phone network operators and their relationship intentions towards their cell phone network operators, one-way ANOVAs were performed. Table 4 exhibits the mean, standard deviation (SD) and d-value (effect size) when comparing the relationship intentions of respondents using Vodacom, MTN and Cell C, by examining the three factors for which statistical significance was found.

Table 4: Effect sizes of relationship intention towards the three cell phone network operators

\begin{tabular}{|c|c|c|c|c|c|c|c|c|}
\hline \multirow[b]{2}{*}{ Factors } & \multirow[b]{2}{*}{ Mean } & \multirow[b]{2}{*}{ SD } & \multirow[b]{2}{*}{$\mathbf{n}$} & \multirow{2}{*}{$\begin{array}{c}\text { Comparisons } \\
\begin{array}{c}\text { significant at the } 0.05 \\
\text { level }\end{array}\end{array}$} & \multirow[b]{2}{*}{ Operator } & \multicolumn{3}{|c|}{ d-value } \\
\hline & & & & & & $\begin{array}{r}\text { Vodacom } \\
\text { (1) }\end{array}$ & $\begin{array}{c}\text { MTN } \\
\text { (2) }\end{array}$ & $\begin{array}{r}\text { Cell C } \\
(3) \\
\end{array}$ \\
\hline \multirow{3}{*}{ Factor 1: Expectations } & 4,30 & 0,69 & 115 & \multirow{3}{*}{$\begin{array}{l}1-3 \\
2-3\end{array}$} & Vodacom (1) & & 0,11 & 0,42 \\
\hline & 4,23 & 0,63 & 101 & & MTN (2) & 0,11 & & 0,32 \\
\hline & 3,98 & 0,77 & 99 & & Cell C (3) & 0,42 & 0,32 & \\
\hline \multirow{3}{*}{ Factor 3: Involvement } & 3,79 & 0,76 & 115 & \multirow{3}{*}{$\begin{array}{l}1-3 \\
1-2\end{array}$} & Vodacom (1) & & 0,48 & 0,45 \\
\hline & 3,36 & 0,90 & 101 & & MTN (2) & 0,48 & & 0,03 \\
\hline & 3,39 & 0,90 & 99 & & Cell C (3) & 0,45 & 0,03 & \\
\hline \multirow{3}{*}{$\begin{array}{l}\text { Factor 5: Fear of } \\
\text { relationship loss }\end{array}$} & 2,86 & 0,96 & 115 & \multirow{3}{*}{$1-3$} & Vodacom (1) & & 0,21 & 0,34 \\
\hline & 2,63 & 1,08 & 101 & & MTN (2) & 0,21 & & 0,14 \\
\hline & 2,48 & 1,13 & 99 & & Cell C (3) & 0,34 & 0,14 & \\
\hline
\end{tabular}

*Tukey's comparison significant at the 0.05 level 
Initial analyses found statistically significant differences for three of the relationship intention factors, namely factor 1 (Expectations), factor 3 (Involvement) and factor 5 (Fear of relationship loss) when comparing the relationship intention of respondents using the three cell phone network operators. From Table 4 it is clear that medium and small effect sizes were obtained between the three cell phone network operators for the three relationship intention factors showing statistical significance. For this reason, respondents from the three cell phone network operators do not differ practically significantly in their views of the three relationship intention factors (Expectations, Involvement and Fear of relationship loss).

\section{Conclusions and recommendations}

Despite organisations' best intentions to build relationships with customers, not all customers want to form long-term relationships with organisations. Since valuable resources could be wasted if organisations apply relationship marketing strategies to customers not desiring a relationship with the organisation (Tuominen, 2007:182; OdekerkenSchröder et al., 2003:178), it would be in the best interest of the organisation to identify those customers who want to form a relationship with them.

The primary objective of this study was to determine young adults' relationship intentions towards their cell phone network operators. Findings from this study suggest that the five constructs proposed by Kumar et al. (2003:670) are valid and reliable to measure the relationship intentions of young South African adults towards their cell phone network operators. It is therefore recommended that cell phone network operators segment their customers in terms of relationship intention and identify the factors that contribute most to high relationship intention. Likewise, factors that can cause a low relationship intention should also be identified and pro-actively managed to ultimately contribute to high relationship intentions.

A secondary objective of the study was to establish whether differences exist between young adults with high relationship intentions and those with low relationship intentions with regard to the constructs used to measure relationship intention. It was found that respondents with high relationship intentions differ from respondents with low relationship intentions in terms of the constructs used to measure relationship intention. It can be concluded that respondents with high relationship intentions are more Involved with and Fear losing their relationship with their cell phone network operator more than respondents with low relationship intentions.

It is recommended that cell phone network operators should determine their young adult customers' relationship intentions and focus on those with high relationship intentions. Cell phone network operators should therefore focus on those customers with higher Involvement and greater Fear of relationship loss to differentiate and target customers with high relationship intentions. This will assist cell phone network operators to segment young adults and to focus their relationship marketing efforts on those with high relationship intentions.
The study furthermore determined the influence of relationship length of young adults with their cell phone network operators and their relationship intentions. The benefits of relationship marketing relate to the long-term relationship between the organisation and its customers, resulting in both parties gaining from the relationship over a period of time. It was found that the majority of respondents have a relationship length with their cell phone network operators ranging between three and ten years. In a study of short-term insurance clients (De Jager, 2006:134-135), it was found that relationship length influences relationship intention. However, other studies (Delport, 2009:83; Kumar et al., 2003:670) found that relationship intention does not necessarily depend on the length of relationship. For instance, young adults might remain with their current cell phone network operators because they can only move to another cell phone network operator when their contract expires, or because it is inconvenient to move from one cell phone network operator to another and not because they have relationship intentions towards their cell phone network operators. This study found that young adults, irrespective of the length of their relationship with their cell phone network operators, do not differ in terms of their views of the relationship intention factors. It is therefore concluded that the length of relationship does not influence the relationship intentions of young adults towards their cell phone network operators.

It is recommended that cell phone network operators should not assume that young adults with a contract want to and will continue their relationship with the particular cell phone network operator. Neither a contract nor the length of relationship of young adults is a guarantee that young adults have relationship intentions towards their cell phone network operators. Cell phone network operators should rather consider young adults' relationship intentions than their relationship length when trying to identify customers with whom to establish long-term relationships.

\section{Limitations and directions for future research}

The results of this study are limited to the service setting of cell phone network operators and results cannot be generalised to all service settings. Furthermore, use was made of non-probability sampling, and consequently results are not representative of the entire population.

Future research can explore the influence of culture on customers' relationship intentions, consider the relevance of relationship intention in diverse industries, and determine the influence of relationship intention on customer satisfaction and loyalty. Furthermore, a probability sample is suggested with a wider geographical area and more diverse racial and age groups.

\section{References}

Baran, R.J., Galka, R.J. \& Strunk, D.P. 2008. Principles of customer relationship management. Mason, $\mathrm{OH}$ : Thomson South-Western. 
Belch, M.A., Krentler, K.A. \& Willis-Flurry, L.A. 2005. 'Teen internet mavens: Influence in family decisionmaking', Journal of Business Research, 58(5):569-575.

Berry, L.L. 2000. 'Relationship marketing of services: growing interest, emerging perspectives'. In Sheth, J.N. \& Partivayar, A. (eds.). Handbook of relationship marketing. Thousand Oaks: Sage Publications.

Blythe, J. 2006. Principles and practice of marketing. London: Thomson Learning.

Buttle, F. 2009. Customer relationship management: Concepts and technologies. $2^{\text {nd }}$ Edition. New York.: Elsevier Butterworth-Heinemann.

Cohen, J. 1988. Statistical power analysis for the behavioral sciences. $2^{\text {nd }}$ Edition. Hillsdale, NY: Lawrence Erlbaum Associates.

De Jager, J.N.W. 2006. 'Relationship intention as a prerequisite for relationship marketing: an application on short-term insurance clients'. MCom dissertation, NorthWest University, Potchefstroom Campus.

Delport, H. 2009. 'The relationship intention of customers within banking and life insurance organisations'. MCom dissertation, North-West University, Potchefstroom Campus.

Doke, L. 2009. 'Home-grown products excel as favourite brands: Some welcome local surprises emerged among the winners in this category', Sunday Times, Business Times Top Brands, Aug. 23, p.3.

Doke, L. 2008. 'Swoosh is coolest.' Sunday Times, Business Times - Top Brands Aug. 17, p.3.

Egan, J. 2004. Relationship marketing: Exploring relational strategies in marketing. $2^{\text {nd }}$ Edition. Harlow: Financial Times/Prentice Hall.

Engeseth, S. 2006. 'Tap into couture and customers', Brand Strategy, 200, (March):36-37.

Evans, M., O’Malley, L. \& Patterson, M. 2004. Exploring direct \& customer relationship marketing. $2^{\text {nd }}$ Edition. London: Thomson.

Gamble, R.G., Stone, M., Woodcock, N. \& Foss, B. 2006. Up close \& personal? Customer relationship marketing @ work. $3^{\text {rd }}$ Edition. London: Kogan Page Limited.

Ha, H.Y. 2004. 'Factors affecting online relationships and impacts', Marketing Review, 4(2):189-209.

Kasper, H., Van Helsdingen, P. \& Gabbott, M. 2006. Services marketing management: A strategic perspective. $2^{\text {nd }}$ Edition. Chichester: Wiley.

Kumar, V., Bohling, T.R. \& Ladda, R.N. 2003. 'Antecedents and consequences of relationship intention:
Implications for transaction and relationship marketing', Industrial Marketing Management, 32(8):667-676.

Lamb, C.W., Hair, J.F., McDaniel C., Boshoff, C. \& Terblanche, N.S. 2008. Marketing. $3^{\text {rd }}$ Edition. Cape Town: Oxford University Press.

Laroche, M., Ueltschy, L.C., Abe, S., Cleveland, M. \& Yannopoulos, P.P. 2004. 'Service quality perceptions and customer satisfaction: Evaluating the role of culture', Journal of International Marketing, 12(3):58-85.

Liang, C.J. \& Wang, W.H. 2006. 'The behavioural sequence of the financial services industry in Taiwan: Service quality, relationship quality and behavioural loyalty', Service Industries Journal, 26(2):119-145.

Ling, I.L. 2008. 'Counterconformity: An attribution model of adolescents' uniqueness-seeking behaviours in dressing', Adolescence, 43(172):881-893.

Little, E. \& MarandiI, E. 2003. Relationship marketing management. London: Thomson Learning.

Lovelock, C.H. \& Wirtz, J. 2007. Services marketing: People, technology, strategy. $6^{\text {th }}$ Edition. Upper Saddle River, N.J.: Pearson/Prentice Hall.

Mentz, M.H. 2007. 'Verhoudingsvoorneme van klante in die Suid-Afrikaanse motorbedryf'. MCom dissertation, University of the Free State, Bloemfontein.

Moroz, Y. 2008. 'Image and personality key to branding Gen Y appeal', Retailing Today, 47(1):5-26.

Odekerken-Schrőder, G., De Wulf, K. \& Schumacher, P. 2003. 'Strengthening outcomes of retailer-consumer relationships: The dual impact of relationship marketing tactics and consumer personality', Journal of Business Research, 56(3):177-190.

Parvatiyar, A. \& Sheth, J.N. 2000. 'The domain and conceptual foundations of relationship marketing'. In Sheth, J.N. \& Partivayar, A. (eds.). Handbook of relationship marketing. Thousand Oaks: Sage Publications.

Payne, A. 2006. Handbook of CRM: achieving excellence in customer management. Burlington, MA: Elsevier Butterworth-Heinemann.

Pride, W.M. \& Ferrell, O.C. 2010. Marketing. $15^{\text {th }}$ Edition. Mason, $\mathrm{OH}$ : South-Western.

Ruiz, D.M., Castro, C. B. \& Armario, E.M. 2007. 'Explaining market heterogeneity in terms of value perceptions', Service Industries Journal, 27(8):1087-1110.

Seiders, K., Voss, G.B., Grewal, D. \& Godfrey, A.L. 2005. 'Do satisfied customer buy more? Examining moderating influences in a retailing context', Journal of Marketing, 69(4):26-43. 
Sprinthall, R.C. 2003. Basic statistical analysis. $7^{\text {th }}$ Edition. Boston, MA: Pearson Education Group.

Steyn, H.S. 1999. Praktiese beduidendheid: Die gebruik van effekgroottes. Potchefstroom: Publikasiebeheerkomitee Potchefstroomse Universiteit vir Christelike Hoër Onderwys.

Steyn, T.F.J., Mostert, P.G. \& De Jager, J.N.W. 2008. 'The influence of length of relationship, gender and age on the relationship intention of short-term insurance clients: An exploratory study', South African Journal of Economic and Management Sciences, 11(2):139-156.

Tuominen, P. 2007. 'Emerging metaphors in brand management: Towards a relational approach', Journal of Communication Management, 11(2):182-191.

Varki, S. \& Wong, S. 2003. 'Consumer involvement in relationship marketing of services', Journal of Service Research, 6(1):83-91.

Wilson, A., Zeithaml, V.A., Bitner, M.J. \& Gremler, D.D. 2008. Services marketing: Integrating customer focus across the firm. $1^{\text {st }}$ European edition. New York: McGraw-Hill Irwin.

Wong, Y.K. \& Hsu, C.J. 2008. 'A confidence-based framework for business to consumer (B2C) mobile commerce adoption', Personal and Ubiquitous Computing, 12(1):77-84.

Zikmund, W.G. \& Babin, B.J. 2010. Exploring marketing research. $10^{\text {th }}$ Edition. Mason, OH: Thomson SouthWestern. 